\title{
Aspergillus species from groundnuts (Arachis hypogaea) and mycotoxin production by toxigenic species
}

\author{
Amalina Kamaruddin and Latiffah Zakaria* \\ School of Biological Sciences, Universiti Sains Malaysia, 11800 USM, Pulau Pinang, Malaysia. \\ Email: Lfah@usm.my
}

Received 18 February 2019; Received in revised form 14 June 2019; Accepted 20 June 2019

\begin{abstract}
Aims: Groundnut is an important food crop and is susceptible to contamination by Aspergillus. The present study was conducted to identify Aspergillus spp. from groundnuts as well as to detect mycotoxin production by toxigenic species. Methodology and results: Molecular identification using ITS region, $\beta$-tubulin and calmodulin genes identified six species, A. niger, A. tubingensis, A. flavus, A. aculeatus, A. sydowii and A. fumigatus. Phylogenetic tree of combined sequences showed the isolates from the same species were grouped with reference strains in the same clade, thus the species identity was confirmed. Detection of mycotoxin biosynthesis genes can give an indication of mycotoxin production. Two ochratoxin A genes, PKS15KS and PKS15C-MeT were detected in seven A. niger isolates but none of the isolates produced ochratoxin $A$ when quantification was conducted using Ultra-High Performance Liquid Chromatography. Two aflatoxin B1 biosynthesis genes, Nor-1 (norsolorinic acid) and Ver-1 (Versicolorin) genes were detected in $A$. flavus but only $\mathrm{KDH} 7$ and $\mathrm{KL} 27 \mathrm{~b}$ isolates produced aflatoxin B1 with concentrations of $1.0 \mu \mathrm{g} / \mathrm{g}$ and 1.1 $\mu \mathrm{g} / \mathrm{g}$, respectively.

Conclusion, significance and impact of the study: Various species of Aspergillus found on groundnuts may lead to potential mycotoxin contamination as toxigenic species were also recovered. The occurrence of Aspergillus spp. can reduce the quality of the legumes as well as reducing their shelf life.
\end{abstract}

Keywords: Aspergillus, groundnuts, molecular identification, ochratoxin A, aflatoxin B1

\section{INTRODUCTION}

Groundnut (Arachis hypogaea) or peanut is a legume belonging to the family Fabaceae. In Malaysia, groundnut is often used as an ingredient in cooking. Groundnuts are commercialised as raw or roasted, salted and consumed as a snack. Raw shelled groundnuts are available in almost all supermarkets and sundry shops in Malaysia.

Groundnuts cultivation and production are not extensive in Malaysia. The crop is more suitable to be used as crop rotation which is locally grown in rotation with other crops as well as grown as intercrop in smallholders farm. Groundnuts are grown in the riverine and in rainfed rice areas in Kelantan, Terengganu, Kedah and Pahang (Halim and Ramli, 1980).

Groundnuts are mainly imported from Vietnam, USA China, Thailand and Hongkong. A total of 44,871 tonnes of groundnuts were imported, mainly in the form of shelled nuts as a response to high demands (Halimah and Lum, 1992).

Groundnuts are imported across the world and thus contamination can easily occur. Under favourable conditions during storage either in the shops and markets or shipments in long journey, groundnuts are prone to spoilage and contamination by diverse groups of microorganisms particularly storage fungi. One of the storage fungi which are widely distributed is Aspergillus spp. which can cause contamination in storage products including groundnuts.

Groundnut contamination by Aspergillus might cause health risk to human and livestock as groundnuts are commonly consumed directly. Moreover, mycotoxins that may be present in groundnuts are also toxic and have harmful effects on animals and humans. Identification of Aspergillus spp. and mycotoxin detection are important for implementing suitable control strategies for groundnuts storage and this will lead to improving quality control of groundnuts for consumer safety. Thus, the present study was conducted to molecularly identify Aspergillus species contaminating groundnuts and to determine the ability of toxigenic species, $A$. niger and $A$. flavus to produce ochratoxin $A$ (OTA) and aflatoxin B1 (AFB1). 


\section{MATERIALS AND METHODS}

\section{Fungal isolates}

Aspergillus isolates were isolated from groundnuts using surface sterilization and direct plating methods (Samson et al., 2010). The groundnuts were purchased from sundry shops and supermarkets in Kuala Lumpur, Pulau Pinang, Sarawak, Kedah, Johor, Perak and Terengganu. The groundnuts in sundry shops and supermarkets were stored in gunny sacks or storage bins and were kept at room temperature. A total of $100 \mathrm{~g}$ groundnuts was randomly scooped from the gunny sacks or storage bins and purchased from each shop. The weight of the groundnuts is not vital for isolation of fungi from food and feed, but a sample size of 100 food particles must be used for isolation purposes (Samson et al., 2010).

\section{Molecular identification}

From isolates of Aspergillus isolated from groundnuts, 61 isolates were chosen as representative isolates from 98 morphologically identified Aspergillus species. The isolates were chosen based on similarity of colony colours, shape of conidia, conidiophores and shape of vesicles. The isolates were molecularly identified using ITS region, $\beta$-tubulin and calmodulin genes.

For DNA extraction, mycelia were grown in malt extract broth in Universal bottles with three replicates for each isolate and incubated at $27^{\circ} \mathrm{C}$. Mycelia were harvested after $48 \mathrm{~h}$ as the level of sporulation was low and give a better yield of DNA after extraction.

The mycelia were dried using Whatman No. 1 filter paper, freeze-dried for $48 \mathrm{~h}$ and were ground into fine powder using liquid nitrogen. The fine powder of the mycelia was transferred into a sterile $2.0 \mathrm{~mL}$ microcentrifuge tube and approximately $60 \mathrm{mg}$ of the mycelial powder was weighed for DNA extraction. The DNA was extracted using Invisorb Spin Plant Mini Kit (STRATEC Molecular GmbH, Berlin, Germany) according to the protocols by the manufacturer.

For amplification of ITS region, ITS1 (TCC GTA GGT GAA CCT GCG G) and ITS4 (TCC TCC GCT TAT TGA TAT GC) primers were used as described by White et al. (1990). $\beta$-tubulin gene was amplified using Bt2a (GGT AAC CAA ATC GGT GCT GCT TTC) and Bt2b (ACC CTC AGT GTA GTG ACC CTT GGC) primers (Glass and Donaldson, 1995) and calmodulin was amplified using CMD5 (CCG AGT ACA AGG ARG CCT TC) and CMD6 (CCG ATR GAG GTC ATR ACG TGG) primers (Hong et al., 2005).

PCR amplification of the ITS region, $\beta$-tubulin and calmodulin genes was performed in a total volume of 25 $\mu \mathrm{L}$ containing $0.5 \mu \mathrm{L}$ of genomic DNA, $4.0 \mu \mathrm{L}$ of $25 \mathrm{mM}$ $\mathrm{MgCl}_{2}, 0.5 \mu \mathrm{L}$ of $10 \mathrm{mM}$ dNTP mix, $0.15 \mu \mathrm{L}$ of $5 \mathrm{U}$ Taq polymerase (Promega, Madison, WI, USA) and $4.0 \mu \mathrm{L}$ of $5 \mathrm{mM}$ primers.

PCR was performed using a thermocycler (Bio-Rad MyCycler, Hercules, CA, USA) with the following cycles: initial denaturation at $95{ }^{\circ} \mathrm{C}$ for $5 \mathrm{~min}, 30$ cycles of denaturation at $95{ }^{\circ} \mathrm{C}$ for $30 \mathrm{sec}$, annealing at $58{ }^{\circ} \mathrm{C}$ for ITS region and $56^{\circ} \mathrm{C}$ for both $\beta$-tubulin and calmodulin genes, extension at $72{ }^{\circ} \mathrm{C}$ for $1 \mathrm{~min}$ and final extension at $72{ }^{\circ} \mathrm{C}$ for $5 \mathrm{~min}$. After PCR, the PCR products were sent to a service provider for DNA sequencing.

\section{Phylogenetic analysis}

MEGA5 software (Tamura et al., 2011) was used to perform multiple sequence alignment of the sequences and to generate phylogenetic tree. Phylogenetic tree of combined sequences of ITS region, $\beta$-tubulin and calmodulin were generated as combined sequences can give more accurate species phylogeny (Wiens, 1998). Sequences of ex-type strains of each Aspergillus species were also included in the phylogenetic analysis as reference isolates (Table 1). Aspergillus ustus was also included in the phylogenetic analysis as an outgroup.

Table 1: Ex-type strains of Aspergillus spp. included in phylogenetic analysis

\begin{tabular}{llll}
\hline Species & ITS region & $\beta$-tubulin & Calmodulin \\
\hline A. niger & FJ629337 & GU296687 & FN594540 \\
A. tubingensis & FJ629354 & FJ629305 & FN594448 \\
A. flavus & KU296260 & EF203146 & EF202057 \\
A. aculeatus & AY585558 & HE577806 & EU330198 \\
A. sydowii & NR131259 & EF652297 & EU443971 \\
A. fumigatus & KU296266 & AY685169 & AY689353 \\
A. ustus & NR131284 & EF591727 & EF591719 \\
\hline
\end{tabular}

Maximum-likelihood (ML) method was used to generate the phylogenetic tree. This method provided the most possible outcome and examines all possible topologies and to choose the one that shows the smallest amount of total evolutionary changes (Huelsenbeck, 1995). Nearest-Neighbour Interchange algorithm was used in ML method to search for topologies that fit the data better. Bootstrap values of 1000 replications were used to generate the tree.

\section{Mycotoxin detection}

Eleven isolates of $A$. niger were chosen for OTA analysis and nine isolates of $A$. flavus for AFB1 analysis (Table 2).

\section{OTA gene detection}

The primers used for amplification of OTA genes were PKS15KS primers, PKS15KS-f (5CAATGCCGTCCAACCGTATG-3) and PKS15KS-r (5CCTTCGCCTCGCCCGTAG-3), and PKS15C-MeT primers, PKS15CMeT-f (5-GCTTTCATGGACTGGATG-3) and PKS15C-MeT-r (5-CATTTCGTTGATCCCATCG-3) (Ferracin et al., 2012). These primers were used to amplify polyketide synthase genes which involved in OTA biosynthesis in Aspergillus. The PKS15KS primer was used to amplify DNA fragments corresponding to $\beta$ ketoacyl synthase (KS) domain while PKS15C-MeT amplify DNA fragments corresponding to C- 
methyltransferase (C-Met) domain which are part of putative polyketide synthase gene gene, An15g07920 (Ferracin et al., 2012). Both C-Met and KS domains are found in An15g07920 gene which has been annotated as putative ochratoxin clusters (Pel et al., 2007).

Table 2: Aspergillus isolates used in OTA and AFB1 analyses

\begin{tabular}{|c|c|c|}
\hline Aspergillus spp. & Isolates (OTA) & Isolates (AFB1) \\
\hline A. niger & $\mathrm{KDH} 4$ & \\
\hline A. niger & KDH5 & \\
\hline A. niger & KL19 & \\
\hline A. niger & KL25 & \\
\hline A. niger & KL29b & \\
\hline A. niger & PNGM7 & \\
\hline A. niger & PRK 9b & \\
\hline A. niger & SRW11 & \\
\hline A. niger & PNGT2 & \\
\hline A. niger & PNGT3 & \\
\hline A. niger & TGN2 & \\
\hline A. flavus & & JOH5 \\
\hline A. flavus & & $\mathrm{JOH} 6$ \\
\hline A. flavus & & $\mathrm{KDH} 7$ \\
\hline A. flavus & & $\mathrm{KL} 16 \mathrm{~b}$ \\
\hline A. flavus & & KL27b \\
\hline A. flavus & & KL29a \\
\hline A. flavus & & PRK3 \\
\hline A. flavus & & SRW6b \\
\hline A flavus & & TGN1 \\
\hline
\end{tabular}

PCR amplification was performed in a total volume of $25 \mu \mathrm{L}$ consisting of $0.5 \mu \mathrm{L}$ of genomic DNA, $5.0 \mu \mathrm{L}$ of $5 \times$ green buffer, $4.0 \mu \mathrm{L}$ of $25 \mathrm{mM} \mathrm{MgCl}, 2.5 \mu \mathrm{L}$ of each forward and reverse primers, $0.125 \mu \mathrm{L}$ of Taq DNA polymerase (Promega), $0.5 \mu \mathrm{L}$ of $10 \mathrm{mM}$ dNTP mix (Promega) and sterile distilled water made up to $25 \mu \mathrm{L}$. PCR was run in a thermal cycler (Bio-Rad MyCycler) with the following conditions; initial denaturation at $95{ }^{\circ} \mathrm{C}$ for 4 min, 35 cycles of denaturation at $95{ }^{\circ} \mathrm{C}$ for $1 \mathrm{~min}$, annealing for PKS15KS at $58.8{ }^{\circ} \mathrm{C}$ and PKS15C-MeT at $51^{\circ} \mathrm{C}$ for $1 \mathrm{~min}$, extension at $72{ }^{\circ} \mathrm{C}$ for $1 \mathrm{~min}$, and a final extension at $72{ }^{\circ} \mathrm{C}$ for $7 \mathrm{~min}$.

Agarose gel $(1 \%)$ was used to detect the PCR products. Wealtec Elite 300 power supply and buffer tank GES with $1 \mathrm{X}$ Tris-Borate-EDTA (TBE) buffer were used to run the electrophoresis. FloroSafe DNA stain (1st Base, Malaysia) was used to stain the gel. Electrophoresis was run at $80 \mathrm{~V}, 400 \mathrm{~mA}$ for $60 \mathrm{~min}$. The sizes of the amplified bands were estimated by comparison with 100 bp DNA marker (GeneRulers ${ }^{\text {TM }}$ DNA markers, Fermentas). After electrophoresis, the gel was viewed and visualized using Bio-RAD Molecular Imager Series ${ }^{\circledR}$ Gel Doc ${ }^{\top M}$ XR System and the gel photo was taken using The Discovery Series $^{\mathrm{TM}}$ Quantity One ${ }^{\circledR}$ 1-D Analysis software version 4.6.5.

\section{Aflatoxin B1 gene detection}

Gene detection for AFB1 was performed using Nor-1 (norsolorinic acid) primers, Nor-1-f (5ACCGCTACGCCGGCACTCTCGGCAC-3) and Nor-1-r (5-GTTGGCCGCCAGCTTCGACACTCCG-3) and Ver-1 (Versicolorin) primers, Ver-1-f (GCCGCAGGCCGCGGAGAAAGTGGT) and Ver-1-r (5CGAAAAGCGCCA CCATCCACCCCAATG-3) as described by Rashid et al. (2008). These two primers were used as both primers are highly specific for the genes to be essential for AF biosynthesis (Hussain et al., 2015). These two genes are used to detect the production of AF and able to identify and distinguish aflatoxinproducer with non-aflatoxin producer (Rashid et al., 2008; Hussain et al., 2015).

PCR amplification was performed in a total volume of $25 \mu \mathrm{L}$ by adding $12.5 \mu \mathrm{L}$ of Econo Taq Plus Green $2 \times$ Master mix (Lucigen, Middleton, WI, USA), $0.25 \mu \mathrm{L}$ of each forward and reverse primers, $1.0 \mu \mathrm{L}$ of DNA template and $11 \mu \mathrm{L}$ of sterile distilled water.

PCR amplification was carried out using a thermal cycler (Bio-Rad MyCycler) as follows: an initial denaturation at $95{ }^{\circ} \mathrm{C}$ for $4 \mathrm{~min}$, followed by 30 cycles of denaturation at $95^{\circ} \mathrm{C}$ for $1 \mathrm{~min}$, annealing at $58-62^{\circ} \mathrm{C}$ for $1 \mathrm{~min}$ for both primers, extension at $72^{\circ} \mathrm{C}$ for $30 \mathrm{sec}$, and a final extension at $72{ }^{\circ} \mathrm{C}$ for $10 \mathrm{~min}$. Electrophoresis conditions was the same as to detect OTA genes.

\section{Extraction of Ochratoxin A and Aflatoxin B1}

OTA and AFB1 were extracted based on the method described by Bragulat et al. (2001). The isolates were cultured at three point's inoculation on Czapek Yeast Agar $\left(25^{\circ} \mathrm{C}\right)$ for 7 days. Agar plug $(0.5 \mathrm{~cm}$ diameter) was removed from the centre of the growing colonies. After 7 days, three agar plugs were put in a Bijou bottle and mixed with $0.5 \mathrm{~mL}$ of methanol, shaken vigorously and left for $1 \mathrm{~h}$ at room temperature. After $1 \mathrm{~h}$, the extracts were filtered through syringe filter (PTFE) with diameter of 0.2 $\mu \mathrm{m} \times 13 \mathrm{~mm}$. The extracts were then injected into a small vial with $3 \mathrm{~mL}$ syringe (NIPRO).

\section{Ochratoxin A and Aflatoxin B1 Analysis Using UHPLC-FLD}

\section{Preparation of OTA Standard and OTA Analysis}

OTA standard was purchased from Sigma Aldrich, USA. Stock solution was prepared by dissolving $1 \mathrm{mg}$ of OTA in $1.0 \mathrm{~mL}$ of methanol (HPLC grade). Working standard solutions were prepared in five different concentrations, 2 $\mu \mathrm{g} / \mathrm{g}, 4 \mu \mathrm{g} / \mathrm{g}, 6 \mu \mathrm{g} / \mathrm{g}, 8 \mu \mathrm{g} / \mathrm{g}$, and $10 \mu \mathrm{g} / \mathrm{g}$.

Analysis was performed using an Acquity UHPLC ${ }^{\mathrm{TM}}$ system (Waters) equipped with BEH C18 column $(2.1 \times$ $50 \mathrm{~mm}$ ) connected to Fluorescence (FLR) detector (Waters). The mobile phase was acetonitrile $\left(\mathrm{CH}_{3} \mathrm{CN}\right)$, deionized water and acetic acid $\left(\mathrm{CH}_{3} \mathrm{COOH}\right)$ (57:41:2 $\mathrm{v} / \mathrm{v} / \mathrm{v})$. The samples and standards $(5 \mu \mathrm{L}$ each) were injected into the UPLC system and run for $5 \mathrm{~min}$. 
Excitation and emission wavelength were set at $330 \mathrm{~nm}$ and $440 \mathrm{~nm}$, respectively. The flow rate was $0.2 \mathrm{~mL} / \mathrm{min}$. The retention time and peak heights in the samples were compared with OTA standards using a calibration curve. The samples were quantified by comparing retention time and peak heights in the sample with OTA standards using a calibration curve.

\section{Preparation of Aflatoxin B1 Standard and Aflatoxin Analysis}

Aflatoxin B1 standard was purchased from Sigma Aldrich, USA. Stock solution was prepared by dissolving $1 \mathrm{mg}$ of AFB1 in $1.0 \mathrm{~mL}$ of methanol (HPLC grade). Working standard solutions were prepared in five different concentrations, $2 \mu \mathrm{g} / \mathrm{g}, 4 \mu \mathrm{g} / \mathrm{g}, 6 \mu \mathrm{g} / \mathrm{g}, 8 \mu \mathrm{g} / \mathrm{g}$, and 10 $\mu \mathrm{g} / \mathrm{g}$ respectively. ACQUITY UHPLC ${ }^{\mathrm{TM}}$ system (Waters) equipped with BEH C18 column $(2.1 \times 50 \mathrm{~mm})$ connected to FLD (Waters) was used for AFB1 analysis. Excitation and emission wavelength were set at $330 \mathrm{~nm}$ and 440 $\mathrm{nm}$, respectively. The mobile phases were deionized water, acetonitrile $\left(\mathrm{CH}_{3} \mathrm{CN}\right)$ and methanol (60:20:20 $\mathrm{v} / \mathrm{v} / \mathrm{v})$. The samples and standards (5 $\mu \mathrm{L}$ each) were run for $4 \mathrm{~min}$. The flow rate was $0.2 \mathrm{ml} / \mathrm{min}$. The samples were quantified by comparing retention time and peak heights in the samples with AFB1 standards using a calibration curve.

\section{RESULTS AND DISCUSSION}

\section{Molecular identification}

Internal transcribed spacer region, $\beta$-tubulin and calmodulin genes were successfully amplified and produced a single band of approximately $600 \mathrm{bp}$ for all 81 isolates of Aspergillus spp. except $A$. sydowii that produced $500 \mathrm{bp}$ of $\beta$-tubulin gene. All the isolates molecularly identified using ITS region, $\beta$-tubulin and calmodulin genes were deposited in the GenBank (Accession numbers - ITS : KY593515-KY593495; $\beta$ tubulin : KY587237 - KY587303; KY609932 - KY609941; calmodulin: KY593505-KY593514; KY609922-search of ITS region, $\beta$-tubulin and calmodulin genes, eight species were identified as $A$. niger (35 isolates), $A$. tubingensis (10 isolates), $A$. aculeatus (three isolates), $A$. flavus (nine isolates), $A$. fumigatus (two isolates), and $A$. sydowii (two isolates). The percentage of similarity produced by all isolates ranged from $99-100 \%$.

Phylogenetic relationship of the isolates is shown in Figure 1. From the tree, all the isolates from the same species including the reference isolates were grouped in the same clade. Isolates of $A$. niger (clade A) were separated from $A$. tubingensis (clade B) with 99\% bootstrap value. Both $A$. niger and $A$. tubingensis isolates were grouped with the ex-type strains of $A$. niger and $A$. tubingensis. Clade $C$ consisted of $A$. aculeatus isolates, Clade $\mathrm{D}, A$. fumigatus isolates, Clade $\mathrm{E}, A$, flavus isolates and Clade $\mathrm{F}, A$. sydowii isolates. For molecular identification, sequence analyses of ITS region, $\beta$-tubulin and calmodulin genes were applied. These region and genes are recommended by Samson et al. (2011) for molecular identification of Aspergillus spp. ITS region is the most common region used to differentiate Aspergillus spp. as the region is also used to differentiate species within a section such as to distinguish between $A$. flavus and A. tamari (section Flavi) (Yazdani et al., 2011), as well as between $A$. niger and $A$. tubingensis (section Nigri) (Varga et al., 2007) of which these two species are closely related and their morphological characteristics are similar.

Phylogenetic analyses of combined sequences of ITS, $\beta$-tubulin and calmodulin showed there was very little variation or no variations observed among the isolates of the same species. Similar results were reported by Hong et al. (2005) of which the phylogenetic analysis of $\beta$ tubulin and calmodulin showed little variation among the isolates of $A$. fumigatus and $A$. lentulus. In a study by Krimitzas et al. (2013) using combined sequences of ITS, intergenic spacer region, $\beta$-tubulin and RNA polymerase II genes also did not show any variation among several species including between $A$. niger and $A$. awamori, and $A$. amstelodami and $A$. rubrum. Therefore, based on molecular identification and phylogenetic analysis using ITS, $\beta$-tubulin and calmodulin gene sequences, the identity of the Aspergillus isolates isolated from groundnuts was confirmed.

Aspergillus niger was the most prevalent species isolated from groundnuts, and the species has been reported as common species isolated from Southeast Asian food commodities (Pitt and Hocking, 2009). Aspergillus niger was also the most prevalent species isolated from groundnuts in Pakistan (Rasheed et al., 2004), Eastern Ethiopia (Mohammed and Chala, 2014) and Egypt (Embaby and Abdel-Galel, 2014). In addition to groundnuts, $A$. niger has been isolated from other types of nuts including pecans (Pitt and Hocking, 2009), cashew nuts (Adebajo and Diyaolu, 2003), almonds, pistachios and walnuts (Molyneux et al., 2007).

Aspergillus tubingensis has also been reported as contaminants of groundnut (Palencia et al., 2014). Other than groundnuts, $A$. tubingensis has been found in maize (Palencia et al., 2014) and grapes (Somma et al., 2012). Aspergillus aculeatus has also been reported as contaminants of groundnut (Palencia et al., 2014). Other than groundnuts, $A$. aculeatus is common contaminant of grapes (Somma et al., 2012) and various post-harvest crops such as apples, pears, peaches, citrus, grapes, figs, strawberries, tomatoes, melons, dried fruit, beans, oil seed and nuts (JECFA, 2001).

Aspergillus flavus is one of the most common fungal contaminants of food and feed, as well as the main producer of aflatoxins. This species is also the most widely reported food borne fungus especially in the tropics (Pitt and Hocking, 2009). Aspergillus flavus is prevalent on different types of peanuts in Southeast Asia including pecans (Pitt and Hocking, 2009), cashew nuts (Adebajo and Diyaolu, 2003) almonds, pistachios and walnuts (Molyneux et al., 2007). 


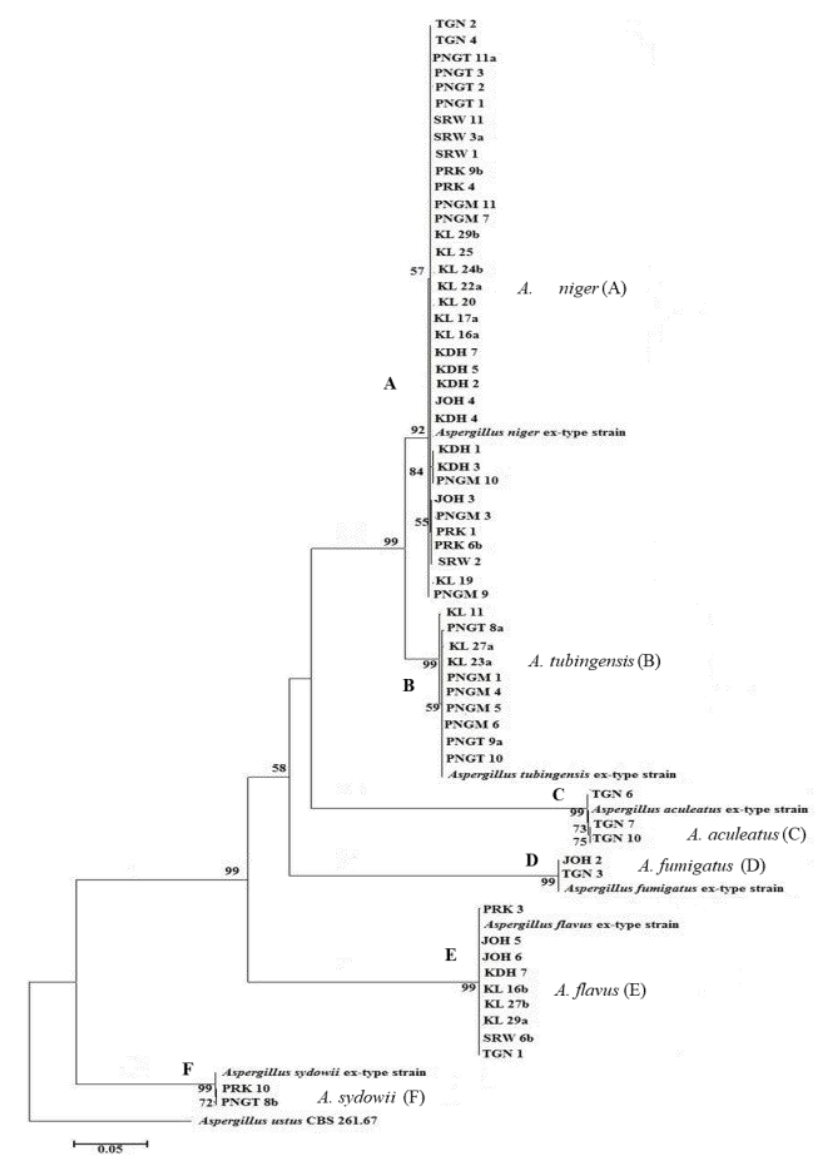

Figure 1: Maximum Likelihood tree generated based on combined sequences of ITS, $\beta$-tubulin and calmodulin of Aspergillus spp. from groundnuts. Aspergillus ustus is the outgroup.

Occurrence of $A$. flavus on groundnuts may lead to aflatoxin production although in the present study, aflatoxin was produced by only two isolates of $A$. flavus. Nevertheless, $A$. flavus is the main source of aflatoxins contamination in the world's food supplies (Pitt and Hocking, 2009). Studies by Rostami et al. (2009), Reddy et al. (2010), Rajarajan et al. (2013) and Guchi (2015) reported that aflatoxigenic $A$. flavus was the most predominant species contaminated groundnuts. Other than groundnuts, A. flavus is also prevalent on wheat, barley, oats, rye, maize and rice (Reddy et al., 2010).

Aspergillus fumigatus has often been recovered from store commodities in the tropics and can grow at low water activity and high temperature (Pitt and Hocking, 2009). Besides groundnuts, $A$. fumigatus has been reported in other types of nuts such as hazelnuts, walnuts and peanuts (Pitt and Hocking, 2009) and cashew nuts (Adebajo and Diyaolu, 2003). The occurrence of $A$. fumigatus has also been reported on other types of food and feed such as dried fish, corn snacks, melon seeds, mango pickles, dried onion and different types of cheese (Pitt and Hocking, 2009); wheat grain (Misra et al., 2010) and maize (Makun et al., 2010). Contamination of $A$. fumigatus on food product may lead to production of metabolites particularly gliotoxin (Sugui et al., 2007) and fumagilin (Fallon et al., 2011).

Aspergillus sydowii is among the storage fungi found in Southeast Asian food and feed commodities. Pitt and Hocking (2009) reported that $A$. sydowii is commonly found on dried foods, including various types of nuts such as peanuts, pistachios, hazelnuts, walnuts and pecans. Aspergillus sydowii has been recovered from cereals such as barley, wheat, flour and pepper samples (Pitt and Hocking, 2009). Thus, it is not surprising that $A$. sydowii was recovered from groundnuts in the present study.

\section{OTA gene detection and quantification}

Seven isolates of $A$. niger produced the PKS15KS band which was approximately $776 \mathrm{bp}$ and the PKS15C-MeT, $998 \mathrm{bp}$ band. For analysis and quantification of OTA using UHPLC, the production of OTA by the Aspergillus isolates were detected by comparison of retention times with OTA standards at $2.9 \mathrm{~min}$. None of the $A$. niger isolates produced OTA even though PKS15KS and PKS15C-MeT genes were detected in seven isolates of A. niger (KDH4, KL 19, KL 25, PNGM 7, PRK 9b, SRW11 and PNGT 3). From this analysis, OTA was not produced by $A$. niger isolates from groundnuts.

\section{Aflatoxin B1 gene detection and quantification}

Nor-1 and Ver-1 genes were detected in nine A. flavus isolates (JOH5, JOH 6, KDH7, KL16b, KL27b, KL29a, PRK3, SRW6b and TGN and KL6. A single band of approximately $400 \mathrm{bp}$ for Nor-1 and 600 bp for Ver-1 gene were produced.

The production of AFB1 was detected at similar retention time with AFB1 standards at $1.9 \mathrm{~min}$. Among the nine isolates of $A$. flavus, only two isolates produced AFB1 (KDH7 and KL27b). The concentration levels of AFB1 produced by isolate $\mathrm{KDH} 7$ was $1.0 \mu \mathrm{g} / \mathrm{g}$ and isolate $\mathrm{KL} 27 \mathrm{~b}, 1.1 \mu \mathrm{g} / \mathrm{g}$.

OTA is a mycotoxin produced by several species of Aspergillus including $A$. niger, $A$. ochraceus, $A$. carbonarius and $A$. melleus which can contaminate various agricultural products. The first step to detect OTA production is to detect OTA biosynthesis genes. In this study, PKS15KS and PKS15C-MeT genes were detected in seven $A$. niger isolates. Both genes encode polyketide synthase genes in OTA biosynthesis (Ferracin et al., 2012; Kim et al., 2014). Similar to the present study, PKS15KS and PKS15C-MeT genes were used to detect the ability of $A$. niger isolates from Korean fermented food to produce OTA (Kim et al., 2014).

From 11 isolates of $A$. niger, PKS15KS and PKS15CMeT genes were not detected in four isolates of $A$. niger (KDH 5, KL 29b, PNGT 2 and TGN 2) and may indicate that these isolates are non OTA producer. The results of this study were similar to a study by Kim et al. (2014) whereby PKS15KS and PKS15C-MeT genes were not 
detected in 16 isolates of $A$. niger from various Korean foods.

Based on UHPLC analysis, the seven isolates of $A$. niger (KDH4, KL 19, KL 25, PNGM 7, PRK 9b, SRW11 and PNGT 3) that were positive for OTA genes did not produce OTA. This might be due to the deletion or mutation of OTA gene clusters (Kim et al., 2014). The loss of the ability to produce OTA by $A$. niger might also be associated with deletion of nucleotides of the gene within the OTA gene clusters (Massi et al., 2016).

Besides mutation of OTA gene, environmental factors particularly water activity and temperature can also play a role on OTA production by $A$. niger. Milani (2013) reported that the production of OTA is at optimum temperature of 25 to $30^{\circ} \mathrm{C}$ and $0.98 \mathrm{aw}$. These conditions are common conditions where groundnuts are stored and the possibility of OTA production by ochratoxigenic fungi is higher. Production of OTA can occur in a few days if certain environmental conditions such as temperature, humidity and water activity are met.

OTA contamination in warm temperate areas and tropical region could be associated with $A$. ochraceus and black Aspergilli. According to Amezqueta et al. (2004), OTA can be produced by $A$. niger at $25-30{ }^{\circ} \mathrm{C}$ and 0.95 $0.99 a_{w}$. Therefore, fast drying and humidity control of food and feed in storage are necessary to avoid fungal invasion and toxin production.

Magnoli et al. (2007) reported that $A$. niger from stored peanuts produced OTA. In contrast, Sultan and Magan (2010) reported that none of $A$. niger isolates from groundnuts produced OTA which is similar with the present study. The results showed that the presence of PKS15KS and PKS15C-MeT genes were not necessarily an indication of OTA production. Although $A$. niger from groundnuts did not produce OTA, other species of black aspergilli have been reported to produce OTA, for example, A. ochraceus from peanut butter (Boli et al., 2013), A. awamori, A. carbonarius and A. japonicus from stored peanuts (Magnoli et al., 2006).

In the present study, two aflatoxin biosynthesis genes, Nor-1 and Ver-1 genes were detected. Both genes coded for key enzymes for aflatoxin production and are considered as an indicator of aflatoxin production by aflatoxigenic Aspergillus spp. (Rashid et al., 2008; Hussain et al., 2015). In several studies, Nor-1 and Ver-1 genes were initially detected to distinguish between aflatoxin and non-aflatoxin producers (Hussain et al., 2015; Davari et al., 2015).

Nor-1 and Ver-1 genes were detected in all nine $A$. flavus isolates tested in this study. However, based on UHPLC analysis, only two isolates of $A$. flavus (KDH 7 and $\mathrm{KL} 27 \mathrm{~b}$ ) produced AFB1 with concentrations of 1.0 $\mu \mathrm{g} / \mathrm{g}$ and $1.1 \mu \mathrm{g} / \mathrm{g}$, respectively. The inability to produce AFB1 by $A$. flavus might be due to deletion of the gene cluster (Yu et al., 2004). According to Criseo et al. (2001), although Nor-1 and Ver-1 genes are present in some nonaflatoxigenic isolates, occurrence of mutations such as substitution of some bases can cause formation of nonfunctional products.
AFB1 production was only detected in two isolates of A. flavus in which isolate $\mathrm{KDH} 7$ produced $1.0 \mu \mathrm{g} / \mathrm{g}$ of AFB1 and isolate KL27b produced $1.1 \mu \mathrm{g} / \mathrm{g}$. GuezlaneTebibel et al. (2013) classified aflatoxigenic Aspergillus section Flavi according to the concentrations of AFB1 produced on CYA. The four groups of concentration levels were classified as high $(>1.1 \mu \mathrm{g} / \mathrm{g})$, moderate $(0.11$ to $1 \mu \mathrm{g} / \mathrm{g})$, low $(0.011$ to $0.10 \mu \mathrm{g} / \mathrm{g})$ and very low $(0.005$ to $0.01 \mu \mathrm{g} / \mathrm{g}$ ). Based on this classification, isolates $\mathrm{KDH} 7$ and KL27b can be classified as moderate producers, suggesting that are risk of AFB1 contamination of grounduts by $A$. flavus. AFB1 concentration from 24.0 to $87.5 \mu \mathrm{g} / \mathrm{kg}$ has been found in peanuts while in peanut products, from 22.0 to $84.6 \mu \mathrm{g} / \mathrm{kg}$ (Hoeltz et al., 2012). Amiri et al. (2013) reported that AFB1 was detected in several types of nuts including peanuts, almonds, walnuts and hazelnuts with high concentration levels $(0.016$ $15.744 \mu \mathrm{g} / \mathrm{kg}$ ). In addition to nuts, AFB1 has been reported as contaminants in other food products such as maize and brown rice with levels of AFB1 ranging from 0 to $149.32 \mu \mathrm{g} / \mathrm{kg}$ (Karthikeyan et al., 2013) and 1.07 to $24.65 \mu \mathrm{g} / \mathrm{kg}$ (Asghar et al., 2014), respectively.

Seven isolates of $A$. flavus did not produce AFB1 and these isolates are considered as non-aflatoxigenic isolates. Occurence of non-aflatoxigenic isolates of $A$. flavus are common in groundnuts (Yin et al., 2009; Okun et al., 2015). In addition to groundnuts, non-aflatoxigenic A. flavus was also found in maize (Probst et al., 2011; Okun et al., 2015) and cotton seed (Cotty, 1997).

Contamination of Aspergillus on groundnuts may occur during pre-harvest and post-harvest, influenced by several factors such as poor storage condition, mechanical damage when harvesting, inadequate drying and poor transportation condition. Improper handling during pre-harvest including crop rotation, tillage, planting date, irrigation and fertilization which may influence the incidence of Aspergillus infestation especially A. flavus on groundnuts (Torres et al., 2014). Contamination of Aspergillus on groundnuts during post-harvest could be attributed to cleaning, grading, transportation, storage, processing, packaging, and retailing (Kimatu et al., 2012). However, contamination during post-harvest can be prevented by quick drying of pods, controlling storage pests, storing the peanuts at low moisture content less than $10 \%$ and using mechanical threshers (Waliyar et al., 2013).

Occurrence of Aspergillus spp. on groundnuts may lead to contamination of mycotoxin and can be harmful to livestock as well as to human. Mycotoxin contamination can affect the quality of groundnut and may reduce the germination rate with loss of carbohydrate, protein and oil content (Begum et al., 2013). The occurrence of Aspergillus spp. on groundnuts can also reduce the quality of the legumes as well as reducing their shelf life.

\section{CONCLUSION}

Several species of Aspergillus were isolated and identified from groundnuts, namely $A$. niger, $A$. tubingensis, A. flavus, A. aculeatus, A. sydowii and $A$. 
fumigatus. Among the species, A. niger and A. flavus are two well-known toxigenic species. Although polyketide synthase gene involved in OTA biosynthesis were detected in seven isolates of $A$. niger, OTA was not produced by $A$. niger which indicate that $A$. niger isolates from groundnuts are not OTA producers. Aflatoxin biosynthesis gene, Nor-1 and Ver-1 genes were detected in nine isolates of $A$. flavus. However, only two isolates of A. flavus produced AFB1, and is classified as a medium AFB1 producers. The present study showed that the presence of polyketide synthase genes (PKS15KS and PKS15C-MeT) and aflatoxin biosynthesis genes (Nor-1 and Ver-1) do not necessarily lead to OTA and AFB1 production.

\section{ACKNOWLEDGEMENTS}

This work was supported partially by a Research University Grant (1001/ PBIOLOGI / 811307) from the Universiti Sains Malaysia.

\section{REFERENCES}

Adebajo, L. O. and Diyaolu, S. A. (2003). Mycology and spoilage of retail cashew nuts. African Journal of Biotechnology 2, 369-373.

Amézqueta, S., González-Peñas, E., Murillo, M. and Lopez de Cerain A. (2004). Validation of a highperformance liquid chromatography analytical method for ochratoxin A quantification in cocoa bean. Food Additive and Contaminants 21, 1096-1106.

Amiri, M. J., Karami, M. and Sadeghi, E. (2013). Determination of AFB1 in peanut, almond, walnut, and hazelnut in Kermanshah Markets, Iran. International Journal of Agriculture and Crop Sciences 6, 11991202.

Asghar, M. A., Iqbal, J., Ahmed, A. and Khan, M. A. (2014). Occurrence of aflatoxins contamination in brown rice from Pakistan. Iranian Journal of Public Health 43, 291-299.

Begum, M. A. J., Venudevan, B. and Jayanthi, M. (2013). Storage fungi in groundnut and the associate seed quality deterioration- A review. Plant Pathology Journal 12, 127-134.

Boli, Z. A., Zoue, L. T., Alloue-Boraud, W. A. M., Kakou, C. A. and Koffi-Nevry, R. (2013). Proximate composition and mycological characterization of peanut butter sold in retail markets of Abidjan. Journal of Applied Biosciences 72, 5822-5829.

Bragulat, M. R., Abarca, M. L. and Cabaes, F. J. (2001). An easy screening method for fungi producing ochratoxin A in pure culture. International Journal of Food Microbiology 71, 139-144.

Cotty, P. J. (1997). Aflatoxin-producing potential of communities of Aspergillus section Flavi from cotton producing areas in the United States. Mycological Research 101,698-704.

Criseo, G., Bagnara, A. and Bisignano, G. (2001). Differentiation of aflatoxin-producing and non- producing strains of Aspergillus flavus group. Letters in Applied Microbiology 33, 291-295.

Davari, E., Mohsenzadeh, M., Mohammadi, G. and Rezaeian-Doloei, R. (2015). Characterization of aflatoxigenic Aspergillus flavus and $A$. parasiticus strain isolates from animal feedstuffs in northeastern Iran. Iranian Journal of Veterinary Research 16, 150155.

Embaby, E. M. and Abdel-Galel, M. M. (2014). Detection of fungi and aflatoxins contaminated peanut samples (Arachis hypogaea L.). Journal of Agricultural Technology, 10, 423-437.

Fallon, J. P., Reeves, E. P. and Kavanagh, K. (2011). The Aspergillus fumigatus toxin fumagillin suppresses the immune response of Galleria mellonella larvae by inhibiting the action of haemocytes. Microbiology 157, 1481-1488.

Ferracin, L. M., Fier, C. B., Vieira, M. L., MonteiroVitorello, C. B., Varani A. de M., Rossi, M. M., Muller-Santos, M., Taniwaki, M. H., lamanaka, B. T. and Fungaro, M. H. P. (2012). Strain-specific polyketide synthase genes of Aspergillus niger. International Journal of Food Microbiology 155, 137145.

Glass, N. and Donaldson, G. (1995). Development of primer sets designed for use with the PCR to amplify conserved genes from filamentous ascomycetes. Applied and Environmental Microbiology 6,1323-1330.

Guchi, E. (2015). Aflatoxin contamination in groundnut (Arachis hypogaea L.) caused by Aspergillus species in Ethiopia. Journal of Applied \& Environmental Microbiology 3, 11-19.

Guezlane-Tebibel, N., Bouras, N., Mokrane, S., Benayad, T. and Mathieu, F. (2013). Aflatoxigenic strains of Aspergillus section Flavi isolated from marketed peanuts (Arachis hypogaea) in Algiers (Algeria). Annals of Microbiology 63, 295-305.

Halim, H. and Ramli, M. N. (1980). Groundnut production, utilization, research and further research needs in Malaysia. In: Proceedings of the International Workshop on Groundnuts. J. V. Mertin (ed.). International Crops Research Institute for the SemiArid Tropics, India. pp. 233-236.

Hamidah, S. and Lum, K. Y. (1992). Bacterial wilt of groundnuts in Malaysia. Proceedings in the International bacterial wilt symposium, Kaoshiung, Taiwan, pp. 21.

Hoeltz, M., Einloft, T. C, Oldoni, V. P., Dottori, H. A. and Noll, I. B. (2012). The occurrence of aflatoxin B1 contamination in peanuts and peanut products marketed in Southern Brazil. Brazilian Archives of Biology and Technology 55, 313-317.

Hong, S. B., Go, S. J., Shin, H. D., Frisvad, J. C. and Samson, R. A. (2005). Polyphasic taxonomy of Aspergillus fumigatus and related species. Mycologia 97, 1316-1329.

Huelsenbeck, J. P. (1995). The robustness of two phylogenetic methods: Four-taxon simulations reveal a slight superiority of maximum likelihood over 
Neighbour-joining. Molecular Biology and Evolution 12, 843-849.

Hussain, A., Afzal, A., Irfan, M. and Malik, K. A. (2015). Molecular detection of aflatoxin producing strains of Aspergillus flavus from peanut (Arachis hypogaea). Turkish Journal of Agriculture-Food Science and Technology 3, 335-341.

JECFA (2001). Fifty-sixth meeting of the Joint FAO/WHO Expert Commiatee on Food Additives Ochratoxin A. In: Safety evaluation of certain mycotoxins in food. WHO Additives Series 47 and FAO Food and Nutrition Paper 74, 281-416.

Karthikeyan, M., Karthikeyan, A., Velazhahan, R., Madhavan, S. and Jayaraj, T. (2013). Occurrence of aflatoxin contamination in maize kernels and molecular characterization of the producing organism, Aspergillus. African Journal of Biotechnology 12, 5839-5844.

Kim, N. Y., Lee. I. and Ji, G. E. (2014). Reliable and simple detection of ochratoxin and fumonisin production in black Aspergillus. Journal of Food Protection 77(4), 653-658.

Kimatu, J. N., McConchie, R., Xie, X. and Nguluu S. N. (2012). The significant role of post-harvest management in farm management, aflatoxin mitigation and food security in Sub-Saharan Africa. Greener Journal of Agricultural Sciences 2, 279-288.

Krimitzas, A., Pyrrl, I., Kouvells, V. N., KapsanakiGotsi, E. and Typas, M. A. (2013). A phylogenetic analysis of Greek isolates of Aspergillus species based on morphology and nuclear and mitochondrial gene sequences. BioMed Research International, 2013.

Magnoli, C., Hallak, C., Astorea, A., Ponsone, L., Chiacciera, S. and Dalcero, A. M. (2006). Occurrence of ochratoxin A-producing fungi in commercial corn kernels in Argentina. Mycopathologia 161, 53-58.

Magnoli, C., Astoreca, A., Ponsone, M. L., FernandezJuri, M. G., Barberis, C. and Dalcero, A. M. (2007). Ochratoxin A and Aspergillus section Nigri in peanut seeds at different months of storage in Córdoba, Argentina. International Journal of Food Microbiology, 119, 213-218.

Makun, H. A., Anjorin, S. T., Moronfoye, B., Adejo, F. O., Afolabi, O. A., Fagbayibo, G., Balogun, B.O. and Surajudeen, A. A. (2010). Fungal and aflatoxin contamination of some human food commodities in Nigeria. African Journal of Food Science 4, 127-135.

Massi, F. P., Sartori, D., de Souza Ferranti, L., Thie lamanaka, B., Taniwaki, M. H., Vieira, M. L. C. and Fungaro, M. H. P. (2016). Prospecting for the incidence of genes involved in ochratoxin and fumonisin biosynthesis in Brazilian strains of Aspergillus niger and Aspergillus welwitschiae. International Journal of Food Microbiology 221, 9-28.

Milani, J. M. (2013). Ecological conditions affecting mycotoxin production in cereals: A review. Veterinarni Medicina 58, 405-411.
Misra, T., Dixit, J. and Singh, S. (2010). Effect of some co-existing mould on aflatoxin production wheat grains under competitive environment. Indian Journal of Scientific Research 1, 75-77.

Mohammed, A. and Chala, A. (2014). Incidence of Aspergillus contamination of groundnut (Arachis hypogaea L.) in Eastern Ethiopia. African Journal of Microbiology Research 8, 759-765.

Molyneux, R. J., Mahoney, N., Kim, J. H. and Campbell, B. C. (2007). Mycotoxins in edible tree nuts. International Journal of Food Microbiology 119, 72-78.

Okun, D. O., Khamis, F. M., Muluvi, G. M., Ngeranwa, J. J., Ombura, F. O., Yongo, M. O. and Kenya, E. U. (2015). Distribution of indigenous strains of atoxigenic and toxigenic Aspergillus flavus and Aspergillus parasiticus in maize and peanuts agro-ecological zones of Kenya. Agriculture and Food Security 4, 110.

Palencia, E. R., Hinton, D. and Bacon, C. W. (2014). Analyses of black Aspergillus species of peanut and maize for ochratoxins and fumonisins. Journal of Food Protection 77, 805-813.

Pel, H. J., De Winde, J. H., Archer, D. B., Dyer, P. S., Hofmann, G., Schaap, P. J., Turner, G., De Vries, R. P., Albang, R., Albermann, K. and Andersen, M. R. (2007). Genome sequencing and analysis of the versatile cell factory Aspergillus niger CBS 513.88. Nature Biotechnology 25, 221-231.

Pitt, J. I. and Hocking, A. D. (2009). Fungi and Food Spoilage, 3rd edn. Springer, New York, USA.

Probst, C., Bandyopadhyay, R., Price, L.E. and Cotty, P. J. (2011). Identification of atoxigenic Aspergillus flavus isolates to reduce aflatoxin contamination of maize in Kenya. Plant Disease 95, 212-218.

Rajarajan, P. N., Rajasekaran, K. M. and Asha Devi, N. K. (2013). Aflatoxin contamination in agricultural commodities. Indian Journal of Pharmaceutical and Biological Research 1, 148-151.

Rasheed, S., Dawar, S., Ghaffar, A. and Shaukat, S. S. (2004). Seed borne mycoflora of grondnut. Pakistan Journal of Botany 36(1), 199-202.

Rashid, M., Khalil, S., Ahmed, W. and Khan, A. G. (2008). Categorization of Aspergillus flavus and Aspergillus parasiticus isolates of stored wheat grains in to aflatoxinogenics and non-aflatoxinogenics. Pakistan Journal of Botany 40, 2177-2192.

Reddy, K. R. N., Salleh, B., Saad, B., Abbas, H. K., Abel, C. A. and Shier, W. T. (2010). An overview of mycotoxin contamination in foods and its implications for human health. Toxin Reviews 29, 3-26.

Rostami, R., Naddafi, K., Aghamohamadi, A., Najafi Saleh, H. and Fazlzadeh Davil, M. (2009). Survey of peanut fungal contamination and its relationship with ambient conditions in the bazar of Zanjan. Iran Journal of Environmental Health Science Engineering 6, 295300.

Samson, R. A., Houbraken, J., Thrane, U., Frisvad, J. C. and Andersen, B. (2010). Food and Indoor Fungi. 
Utrecht, The Netherlands: Centraalbureau voor Schimecultures.

Samson, R. A., Yilmaz, N., Houbraken, J., Spierenburg, H., Seifert, K. A., Peterson, S. W., Varga, J. and Frisvad, J. C. (2011). Phylogeny and nomenclature of the genus Talaromyces and taxa accommodated in Penicillium subgenus Biverticillium. Studies in Mycology 70, 159-183.

Somma, S., Perrone, G. and Logrieco, A. F. (2012). Diversity of black Aspergilli and mycotoxin risks in grape, wine and dried vine fruits. Phytopathologia Mediterranea 51, 131-147.

Sugui, J. A., Pardo, J., Chang, Y. C., Zarembe, K. A., Nardone, G., Galvez, E. M., Müllbacher, A., Gallin, J. I., Simon, M. M. and Kwon-Chung, K. J. (2007). Gliotoxin is a virulence factor of Aspergillus fumigatus: gliP deletion attenuates virulence in mice immunosuppressed with hydrocortisone. Eukaryotic Cell 6, 1562-1569.

Sultan, Y. and Magan, N. (2010). Mycotoxigenic fungi in peanuts from different geographic regions of Egypt. Mycotoxin Research 26, 133-140.

Tamura, K., Peterson, D., Peterson, N., Stecher, G., Nei, M. and Kumar, S. (2011). MEGA5: Molecular evolutionary genetics analysis using maximum likelihood, evolutionary distance, and maximum persimony methods. Molecular Biology and Evolution 28, 2731-2739.

Torres, A. M., Barros, G. G., Palacios, S. A., Chulze, S. N. and Battilani, P. (2014). Review on pre- and postharvest management of peanuts to minimize aflatoxin contamination. Food Research International 62, 1119.

Yazdani, D., Zainal Abidin, M. A., Tan, Y. H. and Kamaruzaman, S. (2011). Molecular identification of Aspergillus and Eurotium species isolated from rice and their toxin producing ability. Microbiology $\mathbf{8 0}, \mathbf{7 2 0}$ 727.

Varga, J., Due, M., Frisvad, J. C. and Samson, R. A. (2007). Taxonomic revision of Aspergillus section Clavati based on molecular, morphological and physiological data. Studies in Mycology 59, 89-106.

Waliyar, F., Osiru, M., Sudin, H. and Njoroge, S. (2013). Reducing aflatoxins in groundnuts through integrated management and biocontrol. In: Aflatoxins: Finding Solutions for Improved Food Safety. Unnevehr, L. J. and Grace, D.(eds). International Food Policy Research Institute.

White, T. J., Burns, T.D., Lee, S. B. and Taylor, J. W. (1990). Amplification and direct sequencing of fungal ribosomal RNA genes for phylogenetics. In: PCR Protocols: A guide to Methods and Applications. Innis, M.A., Gelfand, D.H., Sninsky, J. J. and White, T. J. (eds). Academic Press, San Diego, California. pp. 315-322.

Wiens, J. J. (1998). Does adding characters with missing data increase or decrease phylogenetic accuracy? Systematic Biology 47, 625-640.

Yin, Y., Lou, T., Yan, L., Michailides, T. J. and Ma, Z. (2009). Molecular characterization of toxigenic and atoxigenic Aspergillus flavus isolates, collected from peanut fields in China. Journal of Applied Microbiology 107, 1857-1865.

Yu, J., Chang, P. K., Ehrlich, K.C., Cary, J. W., Bhatnagar, D., Cleveland, T. E., Payne, G. A., Linz, J. E., Woloshuk, C. P. and Bennett, J.W. (2004). Clustered pathway genes in aflatoxin biosynthesis. Applied and Environmental Microbiology 70, 12531262. 